\title{
Reflecting on death through song among the Shona people of Zimbabwe.
}

\author{
Richard Muranda \\ Midlands State University, Zimbabwe \\ randaphy@gmail.com
}

\begin{abstract}
Singing is undertaken by individuals and the community in dealing with real life experiences including death. Death is a reality which humans and animals are not immune to. It defines the end of life and brings pain to humanity. However, humans have mechanisms to deal with pain caused by death, and singing is one of them. The article examines how song is used to tackle the inevitable incidence of death. In this study, traditional and contemporary popular songs were purposively sampled to analyse and reflect on the nature of music used to cope with death. The study engaged 20 people, among them musicians and the elderly. Basing on Kubler-Ross' (1969) five stage DABDA model of dealing with grief, the paper contends that Shona people celebrate life and death through song. Through singing, the Shona express ways of dealing with death. Some Shona beliefs in life after death inform the paper with ways of dealing with pain and how subsequently the Shona people come to accept the reality of death. The bereaved also exhibit some spirited embodiment, and reverence of the departed regardless of their earthly conduct. The study concludes that through song, the Shona people draw solace, hope, and peace of mind with regard to life after death. The frame of mind that accepts the imminence of death is embraced by many as they prepare for death through preparatory moves in taking funeral and general insurance policies. The engagement into singing tends to weaken the sting of death.
\end{abstract}

Key words: acceptance, beliefs, dance, death, denial, grief, song

\section{Introduction}

There are several African myths, legends, and tales that attempt to explain the reason why death is part of humanity. Kirwen (2008, p.208) describes death as "an inevitable event in the personal history of every living person..." From a common religious point of view, the unavoidable occurrence of death is largely explained as the passage from one world to the other. Mbiti (1975, pp. 116-117) and Zahan (1979, pp.36-43) hold the view that death is a reality described through myths. Certain traditions hold that death comes upon humanity as punishment to serious violations of principles 
instituted by the supreme creator, God. According to Mbiti (1975) and Banda (2014), most societies believe death is the end of life on earth and nothing more beyond it. In spite of the various beliefs and mythologies that try to explain death, people generally find death as a surprise whenever it takes effect, especially when it is least expected. Hence, death brings shock and surprise to the remaining members of the immediate and extended families among the Shona and other people.

Based on the above, death brings some suffering, awe, and grief to those left behind. In other belief systems, death is regarded as caused by some human errors otherwise without such mishaps, human beings were meant to be immortal (Mbiti, 1975). Many African societies level blame on external spiritual or physical forces, humans, and animals as causal to the inescapable occurrence of death. Growing up in our Shona culture, the researcher was exposed to the belief that death was always caused by something, hence, elders always strived to find the cause of death.

Traditionally, in Shona, family members of the deceased visit a traditional healer $n$ 'anga to find the reason behind the death of their relative (kugata). Kugata affirms the notion that death is always caused by something hence it is critical for the surviving members to find a solution to avoid the cause before it wipes every member (Mhaka, 2014; Mwandayi, 2011). They also do it as a way to prepare for bringing the spirit of the deceased back home to rest amongst his own people through kurova guva (Vambe, 2009; Rutsate, 2010; Matiure, 2009; 2017). Mbiti (1975, p.118) and Gehman (1989, p.54) also mention that in African contexts, death is regarded as an unnatural experience and it is alleged that witches, spirits or curses are the primary causative forces behind it.

The fact that death brings pain and sorrow to families, compels the Shona people to attend funerals in order to comfort the bereaved and encourage them to accept the sad reality of death. The end result of such endeavours, in many cases, often result in either denial or acceptance of death. Some members of the mourning family can accept while others may remain in denial. In light of the views postulated by Benyera (2014); Mhaka, (2014); Mwandayi, (2011); Vambe (2009) and Matiure (2009) Africans conduct rituals connected to death and at certain times they 'jubilantly' celebrate life of the departed relatives through song depicting the deceased's character as memorial acts.

\section{Aim of Study}

This paper explores Shona people after undertaking studies of this ethnic group from which the researcher belongs. Even though he is aware of the existence of other ethnic groups in Zimbabwe to which differing funeral rites may obtain, he chose to focus on the Shona to depict a clear distinction between Shona and other dialects let 
alone American, Asian, and European, and or other ethnicities for that matter.

\section{Theory and Methodology}

In addition to the traditional Shona beliefs this article draws from the Kübler-Ross (1969) model, which proffers five stages DABDA in managing grief. The theory begins with 'denial' and isolation as the affected person gets into the inexorable situation not accepting grief. Often times the affected individuals dismiss the source of grief at this stage. However, Kübler-Ross (1969) refers to denial only as a temporary defence which is followed by some other course of action. After 'denial,' the grieved turn to anger, bargaining, depression, and finally reach the point of accepting the sad reality.

Kübler-Ross (1969) articulates that 'anger' makes the affected person to regard grief as an unfair occurrence and resents the grief asking such questions: Why me? Why did it happen to him/her? Upon realising that anger and feelings of rage are unsustainable the individual then resort 'bargains' with the situation negotiating for hope within the terrible conditions. Psychologically, the individual asks for more time to set issues into order for example taking care of his/her minor children and or finishing off some building project that needs urgent attention including other pressing matters of concern.

The fourth stage according to Kübler-Ross (1969) is 'depression' which sets in as individuals lose hope because of they are juxtaposed with grief, hence at this stage they see no value in life, people and all things around them hence they lose interest in living. Kübler-Ross (1969) recommends that at the stage of depression the affected should not be cheered. It is necessary for the grieving person to go through such an experience because it prepares them to the eventual fate of death. The last stage is 'acceptance' of the experience of suffering, in this phase the grieved (one facing imminent death) comes to terms with the reality of their mortality or that of their loved one. It is at this stage that the affected people openly discuss and/or sing about their grief (death) and they find no other way out but to accept the sad reality of death. With such a mind-set, the grieved can live normal lives with others without getting worried about their fate. In this article, the five stages have been applied to analyse how people deal with death through song.

The study used a qualitative research methodology with interviews employed to solicit information from 20 people selected purposively, involving musicians and senior citizens among the Shona people. Textual analysis was also done on selected songs of the lyrical content that dealt with the occurrence of death. The study also draws from the concept of life-after-death; a belief held true by several religions some of them being Christianity, Islam, and African Indigenous Religions. This belief in 
life-after-death informs acceptance of the reality of death among the Shona people. Such a belief can defy the five stages in Kübler-Ross's (1969) model as Christian faith gives a hopeful option of acceptance. The folk song Guva rangu, (My grave), a Chimurenga war song Amai nababa musandicheme, (My father and mother do not mourn me), the Tongai Moyo's Sungura song Masimba aMwari (God's power) and Somandla Ndebele's Christian hymnal Ndofamba (I walk, I walk), are songs chosen on the basis that they articulate issues concerning death. The songs help to decipher and analyse the thoughts of the Shona in connection with the unavoidable incidence of death.

\section{Beliefs in Death}

Mwandayi (2011, p.216) mentions that, "After death, the spirit in the eyes of the Shona acquires new spiritual powers as it passes to a completely novel existence in the community of spirits." By implication, the passing on of a person places them into a world where they have power over those that remain behind. In a sense, it gives those that are dying a sense of hope as they will end up in the spirit world with unending authority. In addition, Banana (1991) mentions that life is an endless institution and death is only a passage from the world of visible beings to that which is unseen. In support of Banana (1991), Mhaka (2014, p.380) submits that "[d]eath is viewed as a departure, not an end of life" In relation to the above, life is an unending gift given to humans and death is not a factor.

Among the Shona people, the above beliefs are held strongly and the dead are treated with great respect because the dead are believed to have great influence over the lives of those that remain behind (Saidi, 2017). Citing Gelfand, (1970), Mtapuri and Mazengwa (2013, p.3) say that life is an unending regardless of death however after death, "Mhondoro spirits or 'tutelary spirits' and family spirits (Vadzimu) both originate from the death of people." Whether dead or alive the Shona people cherish that there is hope after death as expressed in the above views.

Mbiti (1969, p.162-165) defines death as when the spirit, often associated with breathing, leaves the body into hereafter. Furthermore, Mbiti (1969) states that the dead person becomes a living dead and relatives still regard as a member of the family. The dead are in the state of personal immortality (Mbiti, 1969 p.163). Christianity through the Bible, refers to matters of life-after-death and as such keen followers of the Christian faith tend to get consoled by the fact that life after death is a guaranteed reality especially to those that believe in it. 
On death, Anderson (2014, p.2) says,

... although a dreaded event, is perceived as the beginning of a person's deeper relationship with all of creation, the complementing of life and the beginning of the communication between the visible and the invisible worlds.

Conversely, the onset of death brings fear in people due to the inevitable end of physical life. However, Paul (Philippians, Chapter 1 v 20-21) mentions that,

I eagerly expect and hope that I will in no way be ashamed ... whether by life or by death. For me, to live is Christ and to die is gain." Paul's words give hope for the future for the Christian faith.

From the above biblical view, death is largely viewed as a transfer from this world to a better place, hence, the prospects to be with God. According to Mbiti, (1969) Christianity and African Indigenous Religion (AIR) concur on the fact that death is a point of transition into the spirit world. Whereas Christianity, in the book of John 3 verse 16, which reads,

For God so loved the world that He gave His only begotten Son, that whoever believes in Him shall not perish, but have eternal life.

The above beliefs underscore that religions embrace in life after death as reality. In AIR people regard the dead as the 'living dead' and their view of death is not different to that of Christians who see Jesus as their intermediary, while in AIR it is held that the ancestors play the mediatory part of the cycle. In the Old Testament, (Ecclesiastes 12 verse 7) the preacher talks about death saying, "...and the dust returns to the ground where it came from, and the spirit returns to God who gave it." The verse connotes death as a divine event for translocation of the human spirit, to the eternal world where it came from believed to be the residence of Almighty God and creator.

Most religions in Africa do not believe in mystery deities rather they accept that there is a supreme being, the creator, and father, residing in the spiritual world. The supreme deity supernaturally presides over spiritual and physical affairs affecting humans on earth. The immortal deity has power to give life and take it away. Beliefs concerning death are expressed through various musical performances and art forms. 


\section{Songs that Speak of Death}

The following section articulates selected songs dealing with death. An analysis of song text and dance routines are undertaken to describe the ways in which Shona people handle grief and pain due to death. The songs deal directly and indirectly with death as given below.

\section{Guvarangu - My grave}

$\begin{array}{lll}\text { Lead: } & \text { Aiyere iyere } & \text { vocables } \\ \text { Response: } & \text { Hoiya ho iyaha hoiya ho haha } & \text { vocables } \\ \text { Lead: } & \text { Aiyere guva rangu } & \text { Oh My grave } \\ \text { Response: } & \text { Kana ndazofa } & \text { When I die } \\ \text { Lead: } & \text { Aiyere guva rangu } & \text { Oh My grave } \\ \text { Response: } & \text { Moise paruware } & \text { Place it on the rock }\end{array}$

The song Guvarangu (My Grave) is sung in a fast tempo in the mbende beat and dance style. The dance celebrates the fertility cult although traditionally it is practiced in restricted indigenous cosmos. Due to modernisation and acculturation it has found place in the public performance spaces in the schools, colleges and among people from other cultures (Matiure, 2009). Mbende has become a customised dance for education and recreational purposes. Here the singer is openly expressing the wish that when he/she dies burial should be on a rock.

The song is sung with a jovial, and exuberant mood interposed with spurts of vigorous dance routines. The singer and dancers take turns to show off in pairs male and female culminating in suggestive sensual physical body conduct. The man grabs the woman to his lap and exits the dance arena as a way to give others a chance to enter the space to show off their acts. Such a routine goes on until the end.

The traditional indigenous context of mbende before the onset political and economic hegemony imposed by the West, would usually involve people who are either married or mutually sensual. Different song themes are brought into play and these set the tone and emotion for the participants. The above song text is calling for something that is difficult to undertake (to dig a grave on a rock). In the Shona context people respect the wishes and rights of the deceased for fear of Ngozi (avenging spirit), reprisals such as spiritual retribution and bad luck to the surviving family members. In life certain requests are not easy to meet however, many Shona people comply with the wishes of their loved ones including the demand in the above song especially if the deceased is an elderly and respectable member of their family, a view that points to life after death as said by Banana (1991) and Mhaka (2014).

In the end, they will have the grave on the rock and enclose the corpse inside. It was observed that such graves were mounted on rock beds in Murehwa, Mutoko, Makoni 
and Buhera districts of Zimbabwe. The song is sung with jubilation prior to one's death and that depicts the acceptance of the reality of death specially to talk about burial. Although this song it is originally associated with the people from Mutoko and Murehwa districts near Harare, (the capital city of Zimbabwe) it is common among the Shona people. The fact that an individual can demand for a specific way to be buried upon death suggests the belief in life beyond death (Mwandayi, 2011).

It is vital to note that in 2013 and 2014 mbende also known as Jerusarema traditional dance, bore the song Guva Rangu for the national competitions in primary schools and colleges in Zimbabwe. In the primary and secondary schools, the song is commonly sung to accompany mbende, even though the discourse of death is petrifying, school pupils sing such songs with ease, and that also depicts the reality of death. Respondents in this study held strongly that singing such a song helps reduce the gravity of the issues that are articulated in the song. Children who sing the above song treat the text of the song like any ordinary song. The singers will most likely not fear death because the song text is not placed within the context of a funeral. However, some ask their teachers on the meaning and that helps to realise reality of death.

\section{Chimurenga song Amai nababa musandicheme}

$\begin{array}{lll}\text { Lead: } & \text { Amai nababa } & \text { My mother and father } \\ \text { Response: } & \text { Amai nababa } & \text { My mother and father } \\ \text { Lead: } & \text { Musandicheme } & \text { Do not mourn for me } \\ \text { Response: } & \text { Musandicheme } & \text { Do not cry for me } \\ \text { Lead: } & \text { Kana ndafa } & \text { If I die } \\ \text { Response: } & \text { Kana ndafa } & \text { If I die } \\ \text { Lead: } & \text { Nehondo } & \text { Because of the liberation war } \\ \text { Response: } & \text { Nehondo } & \text { Because of the liberation war } \\ \text { Lead: } & \text { Ndini } n d a k a z v i d a & \text { It is me who chose } \\ \text { Response: } & \text { Ndini } \text { ndakazvida } & \text { It is me who chose } \\ \text { Lead: } & \text { Kurwira Zimbabwe } & \text { To fight for Zimbabwe } \\ \text { Response: } & \text { Kurwira Zimbabwe } & \text { To fight for Zimbabwe } \\ \text { Lead: } & \text { Kana ndafa } & \text { If I die } \\ \text { Response: } & \text { Kana ndafa } & \text { If I die } \\ \text { Lead: } & \text { Nehondo } & \text { Because of the liberation war } \\ \text { Response: } & \text { Nehondo } & \text { Because of the liberation war }\end{array}$

The above text exhibits a war fighter persuading his/her distant father and mother not to worry about his/her inevitable death because it is a personal decision to fight the war for the liberation of Zimbabwe and he/she has accepted the ultimate fate of death. The text persuades the listeners (in this case parents) to understand that no one is to blame in the event of death at the war front. The song is used to derive and cheer the 
spirit with vigour throughout. Since the singer is at the war zone, the song instils bravery to fight to the end regardless of the impending and inescapable event of death.

The call response portrays a conversation between a storyteller and listeners agreeing on the theme of death. The song text demonstrates that one has come to terms with the reality of death as part of the struggle, and has accepted the fact and there is no going back. The above mind-set is embraced when one is faced with the unavoidable incident of death. At the same time, the person draws solace in the song and gives $\mathrm{him} / \mathrm{her}$ courage and strength to go on with the liberation war undeterred. What prompts such a course of action is the nerve to accept the reality of death (Mhaka, 2014 and Matiure 2009).

\title{
Popular song Masimba aMwari by Tongai Moyo and Somandla Ndebele
}

\author{
Musiki wangu Ishe Mwari samasimba kurarama kwangu kwazondikunda \\ The creator my Lord Almighty, my life has overwhelmed me \\ Ndinozviziva ndikafa nhasi hapana angakwanisa kundimutsa \\ I am aware that if I die today no one can resurrect me from death \\ Kufa mutongo wagarauriko, hazvine mhaka wanangaaniko \\ Death is a foreordained judgment, no matter who faces it \\ Tongai pauri apa urimugwara wakamirira kutorwaneguva \\ Tongai right there you are on your way waiting to face death \\ Soma pauri apa uri mugwara wangomirira kutorwaneguva \\ Soma right there you are on your way waiting to face death \\ Ruzivo makatipa panopanyika zvichienda neshungu dzedupakudzidza \\ Knowledge God gave us on earth according to our zeal to want to learn \\ Chitima chikafa tinomiramira, munhu akafa tinomukonewa
}

If a train dies we can try to fix it, if a person dies we cannot bring them back to life

Ndege ikafa tinomiramira, mwana akafa tinosarenda

If an aeroplane dies we can try to fix it, if a baby dies we surrender

Mota ikafa tinoshingirira, amai vakafatinoyuwira

If a car dies we can bear it all if mother dies we will mourn

Masimba aMwari haanamapitse, kutonga kwaMwari ndikokunoitika

The authority of God cannot be questioned, His judgments prevail

Masimba aMwari haanamapitse, kutonga kwaMwari ndikokunoitika

The authority of God cannot be questioned, even death will prevail

The two musicians Tongai Moyo and Somandla Ndebele express their belief in the Supreme Being as wielding infinite control over humanity. In the song, they reveal that death is supernatural, foreordained and an unavoidable fate that no one can fight but comply with (Mbiti 1975 and Mhaka 2014). The text, Musiki wangu Ishe Mwari 
Samasimba kurarama kwangu kwazondikunda which means, 'The Creator my Lord Almighty, my life has overwhelmed me,' is a statement of acknowledging humans' inability to take charge over death. The opening sentence in the song text shows a person who has abdicated from taking full control of their own life. They accept that dealing with life is the prerogative of the creator (Banana, 1991). The singers proceed to say that no one has the capacity to resurrect a dead person Ndinozviziva ndikafa nhasi hapana angakwanisa kundimutsa meaning, 'I know that if I die today, no one can resurrect me from death.' This is a sign of succumbing to the fate of death (Mhaka, 2014 \& Banda, 2014).

This song depicts an accepted belief among Shona people that there is no power or authority on earth that can challenge death. According to Mbiti (1975), Mazengwa (2013 and Matiure (2017) the text also reveals that even though God has endowed mankind with special abilities, knowledge and wisdom; death transcends these gifts hence there is need for acceptance. In their song, they portray themselves as candidates for eventual death but this is ordered according to time given by the Almighty. In principle, they are saying it is the supreme deity who determines time for one live or die and this cannot be protested (Rutsate, 2010; Matiure, 2009). Another reality is that every living person is waiting for their time to die. The Sungura song, being fast paced, the singers engage in rigorous body movement and dance symbolic of celebration hence their depiction of acceptance of the unpreventable outcome of death.

Revelling in this song leaves the listeners with a mind-set that the singers have now come to terms with the inexorable grief of death and have perhaps accepted it. Their song text does not have attributes of denial, anger, bargain, and depression, which usually pose questions like: Why should I die? How did this come to be? What or who has caused it? The text Masimba aMwari haana mapitse, kutonga kwaMwari ndiko kunoitika, attests to the authority of (Mwari) God whose judgement always prevail. Such an affirmation by the musicians' stresses the inability by humans to resurrect their dead family members hence the supremacy of God (Gelfand, 1970).

Further, God's verdict cannot be vetoed, hence, the prevalence his power. The above song-text arrays an intentional endeavour of man to submit to the authority and power of the supreme deity. The singers personify both the one facing death and the bereaved. All the same they all appreciate the eminence of death. Common among the Shona, people do not question matters of a divine order hence they regard the ultimate occurrence of death as something that should be accepted even though deep inside they may not readily accept it (Zahan, 1979). 
Reflecting on death through song among the Shona people of Zimbabwe.

\section{Ndofamba}

Ndofamba ndosuwa kudenga kunyika yatenzi isina nenhamo

I walk I walk yearning to go to heaven the master's land which has no suffering.

Fambai vatendi kunyika kureyo kunoda vasimbi kusvikayonyika

Walk along believers to the that far land which needs strength to reach it

Hupfumi huriko hakuna hurombo, hakuna neumwe hakuna

Riches are there, there is no poverty, no poor people not even one there is none

Madzinza ariko, kunyika yatenzi havachazochemi havana rusuwo,

Clans are there in the land of the master's land they will not cry and there is no sorrow

Vatsvene variyo vafara zvikuru vaona iyonyenye mufiri wavose

Saints are there are happy to see the Lamb who died for all.

The above song text is a hymnal in Christian church, which bears relevance to the discourse on death and life after death as articulated in bible books of Ecclesiastes and John, and Mwandayi 2011). The wording reveals that the singer is looking forward to going to heaven, a land deemed to be with no suffering. The Christian doctrine has inculcated optimism in hopeless situations that vex people in different ways. The song articulates issues that transcend physical death, holding that there is a post-death world, which is filled with riches and good life. The text ndosuwa kudenga kunyika yatenzi isina nenhamo refers to yearning for the flight to heaven the master's land which is devoid of suffering. After undergoing some suffering, people hope their agony ends with rewards when they get to heaven one day. The text also reveals that those who died earlier than the living have gone to this lovely world and none of them wallows in poverty, all are happy to be with Jesus Christ the Saviour of humanity a view articulated by (Mtapuri \& Mazengwa, 2013).

The text Fambai vatendi kunyika kureyo kunoda vasimbi kusvikayonyika encourages believers to walk to the far land which requires strong people to reach. This text also encourages people to be strong in the journey of faith to heaven. Hupfumi huriko hakuna hurombo, hakuna neumwe neumwe hakuna is instils sense of hope to carry on with their journey with an assurance of riches awaiting them. Reference to Madzinza ariko, kunyika yatenzi havachazochemi havana rusuwo, connotes the ancestors who departed earlier to be living happily with no crying and sadness. The bible speaks of hope in life after death (John 3:16). Furthermore, Vatsvene variyo vafara zvikuru vaona iyonyenye mufiri wavose, refers to saints being part of the population in heaven and that they are happy to see the Lamb (Jesus) who died for all. As a child I used to hear this song at funerals and wondered how this land of peace and riches looked like with the population of all those who had died. As it is sung people in the church draw solace from the promises of peace and riches, and because of that they tend to accept the nemesis of humans through death regardless of the means they depart from the face of the earth. Life after death is a spiritual matter that requires faith in God, not 
reasoning.

\section{Findings}

The informants in the study mentioned that songs in this paper depict feelings of the bereaved, of grief and pain (Kübler-Ross, 1969). As for the singers the songs just articulate direct and indirect feelings toward bereavement. It was gathered that acceptance of grief is not easy to negotiate because the affected always plead for a reprieve to live more time on earth. All the respondents, old and middle aged, concurred that before death humans do not accept that grief is part and parcel of human life, even though they end up with acceptance (Paul in the book of Philipians). In addition, they mostly think that even though there are great promises in the afterdeath dispensation, it is important to live on earth and finish up all the important assignments before death. None of all the 20 informants could not ascertain the reality of the life after death but they held strong beliefs about its existence. As a member of the Shona people, the researcher noted that they do not contend with critical matters of beliefs since doing that is usually deemed to belittle one's faith in the supreme deity (Rutsate, 2010 \& Matiure, 2009).

Again, across the different age groups, all the respondents held true that singing about insurmountable situations like death brings solace and comfort to those experiencing grief and pain. The selected songs helped to understand the process to accepting reality of death. The study shows that individuals are different and they deal with death differently too. However, for musicians' the core business is to entertain the living through informing the world on matters of life and death through music (Zahan, 1979).

Musicians included in the study agreed that sometimes they sing about issues they do not necessarily believe in, just to inform the society. The majority of the interviewed musicians accepted the reality of death however they expressed fear because there is nothing to prevent it, hence singing becomes an effective way to handle death. In this discourse, the information shows that situations of grief are taken to be a source of inspiration for Shona musicians (Matiure, 2017). Musicians compose and sing songs that help to pour out personal inner feelings connected to sorrow and the acceptance of the eventuality of death and grief. Naturally, musicians know that singing is used as a process to water down the sting, striking surprise, seriousness and sadness that come with the occurrence of death especially in situations dominated by denial and anger as the order of the moment. For these reasons, musicians take advantage of the power of music to make brisk business. At the end music helps to arrive at a point of acceptance regardless of the gravity of the situation (Kübler-Ross, 1969).

Songs articulating death prepare members of the society to accept the place of death 
among people regardless of age, the New Testament book of John alludes to this view. Some of the songs are not sacred hence they are sung anytime even in situations where the context has nothing to do with death. It was noted that in schools, songs that depict death are used in traditional dance competitions nationwide, and in music education. This comes as some kind of gradual preparation for death until the time one experiences it directly and or indirectly, acceptance is likely take a less harmful course for the affected. The informants held strong the statement that, "Ndozvazvinoita muhupenyu rufu ruriko" meaning, "That is what happens in life, death is real." Such statements and many others are informed by the experience that people go through in life hence they accept reality of death it becomes a belief among the people (Mtapuri \& Mazengwa, 2013; Mhaka, 2014)

Basing on the information presented in this paper, the Kübler-Ross (1969) model and the responses from the sample of participants in the study, the Shona people do not strictly follow the five stages in the selected songs. Most songs depict anger and acceptance as the most prevalent reactions to the occurrence of death. The songs presented in this article reveal that the Shona people treat death as a spiritual incident which should be celebrated after it occurs although when it happens the affected can easily fall into a state of denial and anger. According to (Mbiti 1975 \& Banda 2014) the Shona people in terms of experience and knowledge subtly through songs believe and accept the sad reality of death.

Shona people generally agree that after death the deceased person becomes absolved of all wrong doings wafa wanaka (after death one is righteous) hence, regarded as a good person. In this way, the deceased is celebrated just like those who died with good earthly reputations. Death is accepted and also celebrated regardless of age and social status of the deceased (Mwandayi, 2011).

\section{Conclusion}

The issues about the way the Shona people deal with death in the real life calls for an understanding of direct and indirect musical activities accompanying these songs. Hence interviewing the people in their natural context can help to find and understand more information about the occurrence of death and the grief that comes with it. Regardless of time given to live on earth unfinished business will always be there and this goes on in everyone's life till death. Therefore, if humans were to be given a chance, death would be postponed many times just to attend to unfinished business. This article recommends deeper researches to examine a wider collection of songs that articulate death among the different ethnic people of Zimbabwe with regards to their real life, genre, beliefs, and cultural contexts. A deeper study can help scholarship to analyse the different ethnicities and their songs especially in view of the application of the Kübler-Ross (1969) theory (DABDA). 


\section{References}

Anderson, A. 2014. Encyclopaedia of Death and Dying: African Religions. Available online at: [Accessed on 11/12/2014]

Banana, C. 1991. Come and Share. Gweru: Mambo Press.

Banda, G. 2014. Life and death: A Biblical view in African context. Available online at: http://www.academic.edu/7099497/LIFE_AND_BIBLICAL_VIEW_IN_AFRIC AN_CONTEXT_Life_and_A_Biblical_View_in_African_Context [Accessed on January 2016]

Benyera, E. 2014. Exploring Zimbabwe's Traditional Transitional Justice Mechanisms. Journal of Social Sciences 4 (3) pp.335-344.

Gehman, R. J. 1989. African Traditional Religion in Biblical Perspective. Kijabe: East African Educational Publishers.

Matiure, P. 2009. The relationship between mbira dzavadzimu mbira modes and Zezuru ancestral spirit possession. (Unpublished Masters of Arts Thesis). University of KwaZulu Natal.

Matiure, P. 2017. Personal Interview. Midlands State University, Gweru. 26 ${ }^{\text {th }}$ July 2017.

Mbiti, J.S. 1969. African Religions and philosophy. Nairobi: East African Educational Publishers.

Mbiti, J.S. 1975. Introduction to African Religion. $2^{\text {nd }}$ Edition. Nairobi: East African Educational Publishers.

Mhaka, C. 2014. Rituals and Taboos Related to Death as Repositories of Traditional African Philosophical Ideas: Evidence from the Karanga of Zimbabwe. Academic Research International. 5 (4) p 377-385. July.

Mtapuri, O. \& Mazengwa, P. J. 2013. Of Spirituality and Poverty: A Zimbabwean Cultural Perspective. Indo-Pacific Journal of Phenomenology. 13(1) p 1-10.

Mwandayi, C. 2011. Death and After-Life Rituals in the Eyes of the Shona: Dialogue with Shona Customs in Quest for Authentic Inculturation. Bamberg: University of Bamberg Press.

Rutsate, J. 2010. "Mhande" dance in the "Kurova guva" ceremony: An enactment of Karanga spirituality. Yearbook for Traditional Music, 42, pp.81-99. 
Reflecting on death through song among the Shona people of Zimbabwe.

Saidi, U. 2017. Agonya neiko mfanha uyu? Of death and funerals - a semiotic exploration of the Shona funeral ritual in Zimbabwe. African Identities. Available Online at: http://dx.doi.org/10.1080/14725843.2017.1319758 [Accessed on 26/04/2017]

The Holy Bible, NIV. 2011. Available online at http://biblehub.com/niv/philippians/1.htm [Accessed on 12/12/2014]

The Holy Bible, NIV. 2011. Available online at http://biblehub.com/niv/john/3.htm [Accessed on 12/12/2014]

The Holy Bible, NIV. 2011. Available online at http://biblehub.com/niv/ecclesiastes/12.htm [Accessed on 12/12/2014]

Vambe, M. 2009. The Function of Songs in the Ritual-Myth of Kurova Guva. Muziki. Journal of Music Research in Africa. 6(1) p 112-119.

Zahan, D. 1979. The Religion, Spirituality and Thought of Traditional Africa. Chicago: Chicago Press. 